\title{
KOSTEN EN JAARREKENINGEN IN GEVAL VAN VERANDERENDE VERVANGINGSWAARDEN
}

\author{
door Prof. Drs. I. van der Zijpp
}

\section{Inleiding}

De verkoopprijzen van veel produkten liggen in perioden met voortdurende inflatie beneden de kostprijzen op basis van de vervangingswaarden der produktiemiddelen. Men verbindt hieraan wel de conclusie, dat de verkoopprijzen dan te laag zijn om een rendabele produktie op lange termijn mogelijk te ma. ken. Deze conclusie is echter niet juist: Als de vervangingswaarden van de door een onderneming gebruikte produktiemiddelen stijgen, liggen de minimaal vereiste opbrengsten beneden de kosten op basis van de vervangingswaarden; als de vervangingswaarden daarentegen dalen, liggen de minimaal vereiste opbrengsten boven de kosten op basis van de vervangingswaarden.

Dat kostprijscalculaties op basis van vervangingswaarden vaak weinig steun aan het verkoopbeleid geven, ervaart men dagelijks op binnenlandse en inter nationale markten. Het is echter niet steeds duidelijk, welke calculatiemetho den dan wel moeten worden toegepast opdat men kostenbedragen vindt die als een maatstaf voor de minimaal vereiste opbrengsten der voortgebrachte eindprodukten kunnen worden beschouwd.

Met onduidelijkheid over de kostencalculatie gaan veelal misverstanden omtrent de jaarrekening gepaard. Wat dit betreft worden veel recente geschriften afgesloten met de opmerking, dat de keuze tussen mogelijke waarderings- en winstbepalingsstelsels afhangt van de zogenaamde handhavingsdoelstellingen van de onderneming. Het laatste is echter een dooddoener. De vraag is juist welke handhavingsdoelstellingen men moet volgen om een betrouwbare grondslag voor het financiële beleid te verkrijgen. ${ }^{1}$ )

Teneinde zinvolle informatie te verkrijgen dient men naar onze mening niet alleen afschrijvingen op basis van vervangingswaarden maar ook herwaarde. ringen in kosten- en winstberekeningen op te nemen. Doordat men zich hier. van niet steeds voldoende bewust is, worden verkoopprijzen in deze tijd soms te hoog gesteld terwijl voordelige verkoopmogelijkheden ten onrechte wor. den afgewezen. Daarenboven geven jaarrekeningen vaak een te pessimistisch beeld van de werkelijk behaalde resultaten.

Hoe herwaarderingen in kosten-en winstberekeningen kunnen worden opgenomen, willen wij in dit artikel trachten toe te lichten. Daarbij beschouwen wij zowel specifieke waardeveranderingen - zoals prijsdalingen tengevolge van technologische verbeteringen en prijsstijgingen wegens het schaarser worden van produktiefaktoren - als algemene waardeveranderingen - d.w.z. prijsdalin gen en stijgingen onder invloed van monetaire faktoren.

\footnotetext{
1) Wij gaan ervan uit, dat de lezer vertrouwd is met de voornaamste opvatringen in de literatuur. Voor een overzicht van de standpunten van verschillende auteurs en instancies kan worden verwezen naar $\mathrm{R}$. Slot en $\mathrm{R}$. M. Vijn, De ontwikkeling van het winstbegrip, Leiden, tweede herziene druk, 1979
} 
Bij gebrek aan plaatsruimte bespreken wij hier alleen waardeveranderingen van duurzame goederen. Voorts beperken wij onze uiteenzettingen door te veronderstellen dat alle betalingen aan het eind van het jaar plaatsvinden en door de belastingen grotendeels buiten beschouwing te laten. Naar wij hopen zal het zonder meer duidelijk worden, dat waardeveranderingen van voorraden niet-duurzame goederen naar analogie van het volgende kunnen worden behandeld en dat de aanbevolen calculatiemethoden bij het loslaten van de gemaakte vereenvoudigende veronderstellingen wel moeten worden uitge. breid maar niet in wezen veranderd. $\left.{ }^{2}\right)$

\section{Aktiva met een onbeperkte gebruiksduur}

Boekwaarden, kosten en winsten kunnen het gemakkelijkst worden bepaald als de beschouwde goederen een onbeperkte gebruiksduur hebben. Om te be. ginnen behandelen wij dan ook de in dit geval te volgen procedures.

Stel, dat een onderneming aan het eind van een bepaald jaar (tijdstip 0) wordt opgericht en dan een grondstuk tegen een prijs van $f 100.000$ koopt. De aanschaf wordt voor $40 \%$ met eigen vermogen en voor $60 \%$ met vreemd vermogen gefinancierd. Het minimaal verlangde rendement over het eigen vermogen is $15 \%$ per jaar terwijl de interest over het vreemde vermogen $10 \%$ per jaar bedraagt. De gemiddelde vermogenskosten, r, zijn dus gelijk aan 12\% per jaar.

Het grondstuk wordt door de onderneming vanaf tijdstip 0 aan een derde verhuurd voor een periode van $n$ jaren. De huuropbrengsten worden jaarlijks per 31 december ontvangen. De interest over het door de onderneming op. genomen vreemde vermogen wordt per 31 december betaald.

De marktwaarde van de grond blijft in de loop der jaren steeds gelijk aan $f$ 100.000. De verhouding tussen het eigen en het vreemde vermogen wordt tot aan het eind van de verhuurtermijn (tijdstip n) op 40/60 gehandhaafd. Het laatste betekent, dat de eigenaren aan het eind van de jaren vóór tijdstip $n$ het verschil tussen de huuropbrengsten en de betaalde interest ontvangen; zij ver. krijgen dus geen vermogensuitkeringen en behoeven ook geen bedragen in de ondernemingskas te storten. Voor zover er een verplichting tot aflossing van vreemd vermogen bestaat, moet de onderneming nieuw vreemd vermo. gen opnemen zodat het totaal vereiste bedrag van $f 60.000$ voortdurend be schikbaar is. Onder deze omstandigheden vertonen de balansen per 31 decem. ber tot aan tijdstip n steeds het volgende beeld.

BALANS PER 31 DECEMBER

\begin{tabular}{|c|c|c|c|}
\hline \multirow[t]{2}{*}{ Grond } & $f 100.000$ & \multirow[t]{2}{*}{$\begin{array}{l}\text { Eigen vermogen } \\
\text { Vreemd vermogen }\end{array}$} & $\begin{array}{ll}f & 40.000 \\
f & 60.000\end{array}$ \\
\hline & $f 100.000$ & & $f 100.000$ \\
\hline
\end{tabular}

De kosten per jaar bestaan in dit geval vanzelfsprekend uit het produkt van de

2) De behandelde materie zal verder worden uitgewerkt in een rond de jaarwisseling te publiceren boek. 
vermogenskosten $r$ en de (constante) marktwaarde van de grond aan het begin van elk jaar. Met het oog op het volgende geven wij de marktwaarde aan het eind van een jaar $t$ in het algemeen weer door $\mathrm{I}(\mathrm{t})$. De kosten, $\mathrm{K}(\mathrm{t})$, zijn dan in elk jaar gelijk aan:

$\mathrm{K}(\mathrm{t})=\mathrm{r} \cdot \mathrm{I}(\mathrm{t}-1)=\mathrm{r} \cdot \mathrm{I}(0)=0,12 \cdot f^{\prime} 100.000=f^{\prime} 12.000$

Het is duidelijk, dat de aldus bepaalde jaarkosten een maatstaf voor de minimaal vereiste jaarlijkse opbrengsten vormen: De contante waarde van een in. vesteringsproject met een investeringsbedrag van $\mathrm{I}(0)$, een reeks jaarlijkse ex. ploitatiesaldi van $r \cdot I(0)$ en een restwaarde van $I(n)=I(0)$ is gelijk aan 0 op basis van de gegeven rentevoet $\mathrm{r}^{3}$ ); de uitvoering van een dergelijk project is dus juist financiëel verantwoord. Zouden de huuropbrengsten in het gegeven voorbeeld in alle jaren gelijk aan de kosten van $f 12.000$ zijn, dan zou men steeds de hiernavolgende resultatenrekening en winstverdeling verkrijgen. In dit ge val kan men aan het eind van elk jaar de interest over het vreemde vermogen betalen en aan de eigenaren een vergoeding over het eigen vermogen geven overeenkomstig het minimaal door hen verlangde rendement. Als de grond na beëindiging van het huurcontract over $\mathrm{n}$ jaren wordt verkocht, kan men het eigen en het vreemde vermogen uit de dan te realiseren marktwaarde terugbetalen.

RESULTATENREKENING EN WINSTVERDELING

Opbrengsten

f 12.000

Interest: $10 \%$ van $f 60.000$

f 6.000

Winst

Mutatie eigen vermogen

f 6.000

$f--$

Storting/Uitkering

f 6.000

Stel nu, dat de marktwaarde van de grond na het tijdstip van aanschaf gaat dalen of stijgen. De relatieve waardeverandering in het jaar vóór tijdstip t stel. len wij voor door $w(t)$, zodat:

$$
I(t)=[1+w(t)] \cdot I(t-1)
$$

Om de gedachten te bepalen beschouwen wij twee mogelijkheden: een constante waardedaling met $10 \%$ per jaar $(w(t)=-0,10$ voor $t=1, \ldots, n)$ en een constante waardestijging met $10 \%$ per jaar $(w(t)=0,10$ voor $t=1, \ldots, n)$. Bij een gebruiksduur van $n=5$ jaren verlopen de marktwaarden dan als volgt:

$$
\begin{aligned}
& \text { 3) }-I(0)+\sum_{i=1}^{n} \frac{r \cdot I(0)}{(1+r)^{t}}+\frac{I(0)}{(1+r)^{n}}= \\
& -I(0)+r \cdot \frac{1-(1+r)^{-n}}{r} I(0)+\frac{I(0)}{(1+r)^{n}}=0
\end{aligned}
$$




\begin{tabular}{lll}
\hline Jaar $(t)$ & Daling & Stijging \\
\hline 0 & $f 100.000$ & $f 100.000$ \\
1 & $f \quad 90.000$ & $f 110.000$ \\
2 & $f 81.000$ & $f 121.000$ \\
3 & $f 72.900$ & $f 133.100$ \\
4 & $f 65.610$ & $f 146.410$ \\
5 & $f 59.049$ & $f 161.051$ \\
\hline
\end{tabular}

Vraagt men zich af welke gevolgen deze waardeveranderingen hebben voor de door het bedrijf te maken calculaties, dan kan primair worden vastgesteld dat het bedrag r.I( 0 ) niet langer de jaarkosten als maatstaf voor de minimaal vereiste jaarlijkse huuropbrengsten aangeeft. De contante waarde van een in vesteringsbedrag $\mathrm{I}(0)$, een reeks jaaropbrengsten r.I $(0)$ en een restwaarde $\mathrm{I}(\mathrm{n})$ is immers kleiner dan 0 als $\mathrm{I}(\mathrm{n})<\mathrm{I}(0)$ en groter dan 0 als $\mathrm{I}(\mathrm{n})>\mathrm{I}(0)$. Bovendien is het a priori duidelijk dat een constant kostenbedrag $\cdot r \cdot I(0)$ of een ander . in geval van waardeveranderingen geen bruikbaar gegeven ter beoordeling van verkoopprijzen of ter oplossing van andere planningvraagstukken vormt.

In plaats van het bedrag $r \cdot \mathbb{I}(0)$ als jaarkosten te beschouwen zou men de vermogenskosten met de vervangingswaarden in de respectievelijke jaren kunnen vermenigvuldigen. Gaat men daarbij uit van de vervangingswaarden aan het begin van het jaar, dan zouden de kosten in jaar t gelijkgesteld moeten worden aan $r \cdot I(t-1)$. De aldus berekende kosten vertonen inderdaad een da lend, resp. stijgend verloop. Voegt men hieraan echter de verkoopwaarde van de grond op tijdstip $n$ toe, dan verkrijgt men een reeks bedragen, $r \cdot I(0), r \cdot I(1)$, $\left.\ldots,\left.\right|_{r} \cdot I(n-1)+I(n)\right]$, waarvan de contante waarde in geval van waardedalin. gen kleiner en in geval van waardestijgingen groter dan $\mathrm{I}(0)$ is. Derhalve geven ook de grootheden $r \cdot I(t-1)$ geen juiste indicatie van de minimaal vereiste jaarlijkse opbrengsten.

De vraag is dus, hoe men dan wel jaarkosten kan berekenen die af- of toe nemen in geval van resp. dalende of stijgende vervangingswaarden, terwijl de contante waarde hiervan bij een restwaarde I(n) gelijk is aan de aanschafprijs van het beschouwde produktiemiddel. Met betrekking tot produktiemiddelen met een onbeperkte gebruiksduur is deze vraag niet moeilijk te beantwoorden: Men kan de gestelde doeleinden bereiken door de kosten in elk jaar gelijk te stellen aan de financieringskosten over de marktwaarde aan het begin van het jaar . d.w.z. de zojuist genoemde grootheden $r \cdot I(t-1)$ - minus de herwaarde ring in het jaar. Onder de herwaardering van een produktiemiddel met een onbeperkte gebruiksduur, $\mathrm{H}(\mathrm{t})$, verstaat men dan het verschil tussen de nieuw. waarden aan het begin en aan het eind van het jaar. Dus: 
$H(t)=I(t)-I(t-1)=w(t) \cdot I(t-1)$

De kosten in jaar $t, K(t)$, bedragen nu:

$$
\begin{aligned}
K(t) & =r \cdot I(t-1)-H(t) \\
& =r \cdot I(t-1)-w(t) \cdot I(t-1) \\
& =[r-w(t)] \cdot I(t-1) .
\end{aligned}
$$

De aldus gedefiniēerde kosten worden in onderstaande tabel op basis van de hierboven gemaakte veronderstellingen berekend. Er kan gemakkelijk worden bewezen, dat de kosten $\mathrm{K}(\mathrm{t})$ tezamen met de restwaarde I(n) een contante waarde ten bedrage van $\mathrm{I}(0)$ opleveren $\left.{ }^{4}\right)$. Zoals blijkt zijn de grootheden $\mathrm{K}(\mathrm{t})$ in geval van waardedalingen hoger dan in geval van waardestijgingen. In het tweede geval liggen de jaarkosten aanvankelijk zelfs beneden de financieringskosten van de aanschafprijs $r$. I $(0)$. Het laatste is in overeenstemming met het ervaringsfeit, dat de aanvangshuren in stijgende onroerend goedmarkten veel-

\begin{tabular}{|c|c|c|c|c|c|c|}
\hline \multirow[t]{2}{*}{ Jaar } & \multicolumn{3}{|c|}{ Waardedaling } & \multicolumn{3}{|c|}{ Waardestijging } \\
\hline & $r \cdot I(t-1)$ & $H(t)$ & Totaal & $r \cdot I(t-1)$ & $H(t)$ & Totaal \\
\hline 1 & $f 12.000$ & $f 10.000$ & $f 22.000$ & $f 12.000$ & $f 10.000$ & $f \quad 2.000$ \\
\hline 2 & $f 10.800$ & $f \quad 9.000$ & $f 19.800$ & $f 13.200$ & $f 11.000$ & $f \quad 2.200$ \\
\hline 3 & $f \quad 9.720$ & $f 8.100$ & $f 17.820$ & $f 14.520$ & $f 12.100$ & $f \quad 2.420$ \\
\hline 4 & $f 8.748$ & $f \quad 7.290$ & $f 16.038$ & $f 15.972$ & $f 13.310$ & $f \quad 2.662$ \\
\hline \multirow[t]{2}{*}{5} & $f \quad 7.873$ & $f \quad 6.561$ & $f 14.434$ & $f \quad 17.569$ & $f 14.641$ & $f \quad 2.928$ \\
\hline & $f 49.141$ & $f 40.951$ & $f 90.092$ & $f 73.261$ & $f 61.051$ & $f 12.210$ \\
\hline
\end{tabular}
al niet de kosten op basis van de aanschafprijzen dekken.

JAARKOSTEN K(t)

Uitgaande van het gegeven voorbeeld kan men de jaarrekeningen op blz. 491 en 492 opstellen. Daarbij wordt wederom aangenomen, dat de verhouding tus.

$$
\text { 4) } \begin{aligned}
& \sum_{t=1}^{n} \frac{K(t)}{(1+r)^{t}}+\frac{I(n)}{(1+r)^{n}}= \\
& \sum_{t=1}^{n} \frac{r \cdot I(t-1)-H(t)}{(1+r)^{t}}+\frac{I(n)}{(1+r)^{n}}= \\
& \sum_{t=1}^{n} \frac{r \cdot I(t-1)-[I(t)-I(t-1)]}{(1+r)^{t}}+\frac{I(n)}{(I+r)^{n}}= \\
& \sum_{t=1}^{n} \frac{(1+r) \cdot I(t-1)}{(1+r)^{t}}-\sum_{t=1}^{n} \frac{I(t)}{(1+r)^{t}}+\frac{I(n)}{(1+r)^{n}}= \\
& \sum_{t=1}^{n} \frac{I(t-1)}{(1+r)^{t}-I}-\sum_{t=I}^{n} \frac{I(t)}{(1+r)^{t}}+\frac{I(n)}{(1+r)^{n}}= \\
& \frac{I(0)}{(1+r)^{0}}-\frac{I(n)}{(1+r)^{n}}+\frac{I(n)}{(1+r)^{n}}=1(0)
\end{aligned}
$$

$m a b$ blz 490 
sen het eigen en het vreemde vermogen op 40/60 wordt gehandhaafd. Ver. der wordt verondersteld, dat de exploitatiesaldi in de respectievelijke jaren gelijk zijn aan de hierboven berekende jaarkosten $\mathrm{K}(\mathrm{t})$ en dat per 31 december van elk jaar $10 \%$ interest over het vreemde vermogen aan het eind van het daaraan voorafgaande jaar moet worden betaald. Tenslotte worden de (negatieve dan wel positieve) herwaarderingen $\mathrm{H}(\mathrm{t})$ in de jaarrekeningen als bestand. delen van de winst beschouwd.

Ter beoordeling van de jaarrekeningen kan men het volgende opmerken:

(a) Het eigen vermogen geeft op elk tijdstip aan, welk bedrag aan de eigenaren zou kunnen worden uitbetaald als de onderneming onmiddellijk zou worden opgeheven. In deze betekenis geeft het eigen vermogen op basis van ver. vangingswaarden dus een zuivere indicatie van de waarde van het bedrijf voor de eigenaren.

De winst is steeds gelijk aan de jaarlijkse opbrengst minus of plus de herwaardering en minus de interest op het vreemde vermogen. Onder de ge. maakte veronderstellingen bedraagt deze winst in elk jaar $15 \%$ van het eigen vermogen aan het eind van het daaraan voorafgaande jaar.

Het eigen vermogen op basis van vervangingswaarden verandert elk jaar met $40 \%$ van de herwaardering. In geval van waardedaling wordt telkens een bedrag aan vreemd vermogen ter grootte van $60 \%$ van de herwaardering afgelost; in geval van waardestijging wordt een bedrag aan vreemd vermogen ter grootte van $60 \%$ van de herwaardering aangetrokken.

Jaarrekeningen in geval van waardedaling $(\times 1000$ gld.)

BALANSEN PER 31 DECEMBER

Jaar 0 Jaar 1 Jaar 2 Jaar 3 Jaar 4 Jaar 5

\begin{tabular}{|c|c|c|c|c|c|c|}
\hline $\begin{array}{l}\text { Debet } \\
\text { Grond }\end{array}$ & 100 & 90 & 81 & 72,9 & 65,6 & 59 \\
\hline \multicolumn{7}{|l|}{ Credit } \\
\hline Eigen vermogen & 40 & 36 & 32,4 & 29,2 & 26,2 & 23,6 \\
\hline \multirow[t]{2}{*}{ Vreemd vermogen } & 60 & 54 & 48,6 & 43,7 & 39,4 & 35,4 \\
\hline & 100 & 90 & 81 & 72,9 & 65,6 & 59 \\
\hline
\end{tabular}




\begin{tabular}{|c|c|c|c|c|c|c|}
\hline & Jaar $O$ & Jaar 1 & Jaar 2 & Jaar 3 & Jaar 4 & Jaar \\
\hline Exploitatiesaldo & - & 22 & 19,8 & 17,8 & 16 & 14,4 \\
\hline Herwaardering & - & 10 & 9 & 8,1 & 7,3 & 6,6 \\
\hline Interest & - & 6 & 5,4 & 4,9 & 4,4 & 3,9 \\
\hline Winst & - & 6 & 5,4 & 4,8 & 4,3 & 3,9 \\
\hline Mutatie eigen vermogen & 40 & -4 & $-3,6$ & $-3,2$ & -3 & $-2,6$ \\
\hline Storting/Uitkering & -40 & 10 & 9 & 8 & 7,3 & 6,5 \\
\hline
\end{tabular}

Jaarrekeningen in geval van waardestijging $(\times 1000$ gld.)

BALANSEN PER 31 DECEMBER

Jaar 0 Jaar 1 Jaar 2 Jaar 3 Jaar 4 Jaar 5

\begin{tabular}{lrrrrrr}
\hline $\begin{array}{l}\text { Debet } \\
\text { Grond }\end{array}$ & 100 & 110 & 121 & 133,1 & 146,4 & 161 \\
$\begin{array}{l}\text { Credit } \\
\text { Eigen vermogen }\end{array}$ & 40 & 44 & 48,4 & 53,2 & 58,6 & 64,4 \\
$\begin{array}{l}\text { Vreemd vermogen } \\
\text { (10 }\end{array}$ & $\frac{66}{110}$ & $\frac{72,6}{121}$ & $\frac{79,9}{133,1}$ & $\frac{87,8}{146,4}$ & $\frac{96,6}{161}$ \\
\hline
\end{tabular}

RESULTATENREKENINGEN EN WINSTVERDELINGEN

\begin{tabular}{lrrrrrrr}
\hline & Jaar O & Jaar l & Jaar 2 & Jaar 3 & Jaar 4 & Jaar 5 \\
\hline Exploitatiesaldo & - & 2 & 2,2 & 2,4 & 2,7 & 2,9 \\
Herwaardering & - & 10 & 11 & 12,1 & 13,3 & 14,6 \\
Interest & - & 6 & & 6,6 & 7,3 & 8 & 8,8 \\
Winst & - & 6 & & 6,6 & 7,2 & 8 & 8,7 \\
Mutatie eigen vermogen & 40 & 4 & & 4,4 & 4,8 & 5,4 & 5,8 \\
Storting/Uitkering & -40 & 2 & & 2,2 & 2,4 & 2,6 & 2,9 \\
\hline
\end{tabular}

(b) Wanneer zich een algemene inflatie voordoet, kan men de winst in twee componenten splitsen:

- de inflatiecorrectie op het eigen vermogen, gelijk aan de inflatiefaktor maal het eigen vermogen aan het begin van het jaar en

- de reële winst of wel de reële beloning voor het beschikbaar stellen van eigen vermogen, zijnde het verschil tussen de winst en de inflatiecorrectie op het eigen vermogen. 
Stel bijv., dat de algemene relatieve prijsverandering in de hier beschouwde gevallen steeds $10 \%$ per jaar is. Aan de resultatenrekening zouden dan de vol. gende posten ( $\times 1000$ gld.) kunnen worden toegevoegd:

WAARDEDALING

Jaar 1 Jaar 2 Jaar 3 Jaar 4 Jaar 5

\begin{tabular}{|c|c|c|c|c|c|}
\hline Winst & 6 & 5,4 & 4,8 & 4,3 & 3,9 \\
\hline Inflatiecorrectie & 4 & 3,6 & 3,2 & 2,9 & 2,6 \\
\hline Reële winst & 2 & 1,8 & 1,6 & 1,4 & 1,3 \\
\hline
\end{tabular}

WAARDESTIJGING

\begin{tabular}{|c|c|c|c|c|c|}
\hline & Jaar 1 & Jaar 2 & Jaar 3 & Jaar 4 & Jaar 5 \\
\hline Winst & 6 & 6,6 & 7,2 & 8 & 8,7 \\
\hline Inflatiecorrectie & 4 & 4,4 & 4,8 & 5,3 & 5,9 \\
\hline Reële winst & 2 & 2,2 & 2,4 & 2,7 & 2,8 \\
\hline
\end{tabular}

Men kan de stelling verdedigen, dat de inflatiecorrectie op het eigen vermogen een ,schijnwinst" is die geheel aan de eigenaren van de onderneming toekomt en waarvan andere winstgerechtigden - met name werknemers en de fiscus - geen deel voor zich zouden mogen opeisen.

Onder de gegeven omstandigheden komen de jaarlijks vereiste reserverin gen in geval van waardestijging overeen met de respectievelijke inflatiecorrecties op het eigen vermogen. Dit behoeft vanzelfsprekend in het algemeen niet het geval te zijn. De vereiste reserveringen en de inflatiecorrecties op het eigen vermogen zijn in het gegeven voorbeeld aan elkaar gelijk doordat hierin geen nieuwe investeringen noch desinvesteringen na tijdstip 0 zijn opgenomen en doordat de algemene inflatiefaktor gelijkgesteld is aan de relatieve waardeverandering van het beschouwde grondstuk. Als niet aan deze veronderstellingen is voldaan, kunnen de jaarlijks vereiste reserveringen zowel groter als kleiner dan de inflatiecorrecties op het eigen vermogen zijn.

(c) Vrijwel alle voorstanders van toepassing van het vervangingswaardestelsel zijn van mening, dat negatieve herwaarderingen als aftrekposten in de winstberekening moeten worden opgenomen. Er bestaat echter geen eenstemmig. heid over de vraag of positieve herwaarderingen als bijdragen tot de winst zijn te beschouwen. Veel auteurs verdedigen een variant van het vervangingswaardestelsel die op het volgende neerkomt:

- De positieve herwaarderingen mogen niet als een bestanddeel van de winst worden beschouwd maar moeten rechtstreeks op de creditzijde van de balans worden opgenomen als een onderdeel van het eigen vermogen. Dit onderdeel van het eigen vermogen wordt veelal met de naam Herwaarderingsreserve aangeduid. 
- De onderneming mag in geen enkel jaar meer dan de winst, excl. de her. waardering, aan de eigenaren uitkeren.

Om de gevolgen van dit systeem te illustreren beschouwen wij onderstaande jaarrekeningen. De aktivawaarden hierin nemen wederom toe met $10 \%$ per jaar. De oorspronkelijke verhouding tussen het eigen en het vreemde ver. mogen is $40 / 60$. Daarna worden de jaarlijkse herwaarderingen aan het eigen vermogen toegevoegd. Het vreemde vermogen blijft dan gelijk aan het aanvankelijke bedrag van $f 60.000$. De opbrengsten zijn in de volgende jaarrekeningen hoger gesteld dan in het hierboven gegeven voorbeeld, opdat de wins. ten na aftrek van de interest ad $10 \%$ op het vreemde vermogen en zonder toe. voeging van de herwaarderingen in alle jaren positief zijn en de eigenaren na jaar 0 dus geen additionele stortingen in de ondernemingskas behoeven te doen.

Doordat de jaarlijkse herwaarderingen volledig - en niet voor $40 \%$ zoals op blz. 491 en 492 is aangegeven - aan het eigen vermogen worden toegevoegd, neemt de verhouding tussen het eigen vermogen en het vreemde vermogen in onderstaande jaarrekeningen geleidelijk toe. Toepassing van deze variant van het vervangingswaardestelsel en de hieraan gekoppelde winstuitkeringsregel heeft m.a.w. een verandering van de vermogensstructuur tot gevolg.

Het zal duidelijk zijn, dat één en ander op een misverstand berust. Er bestaan geen redenen, waarom de verhouding tussen het eigen en het vreemde ver. mogen in geval van stijgende aktivawaarden altijd zou moeten toenemen. Derhalve is de aanbeveling om positieve herwaarderingen in het algemeen volledig te reserveren ongegrond. De uitkeringen aan of de stortingen door de eigenaren (en dus de opnamen van of de aflossingen op het vreemde vermo. gen) kunnen niet op basis van een dergelijke starre regel worden bepaald. Be slissingen hierover moeten op de verwachte ontwikkeling van de aktivawaarden - tengevolge van zowel marktwaardeveranderingen als investeringen en desinvesteringen - en op de daarbij wenselijk geachte verhouding tussen het eigen en het vreemde vermogen worden afgestemd.

BALANSEN PER 31 DECEMBER

Jaar 0 Jaar 1 Jaar 2 Jaar 3 Jaar 4 Jaar 5

$\begin{array}{lrrrrrr}\begin{array}{l}\text { Debet } \\ \text { Grond }\end{array} & 100 & 110 & 121 & 133,1 & 146,4 & 161 \\ \begin{array}{l}\text { Credit } \\ \text { Eigen vermogen }\end{array} & 40 & 50 & 61 & 73,1 & 86,4 & 101 \\ \begin{array}{l}\text { Vreemd vermogen } \\ \text { (100 }\end{array} & \frac{60}{110} & \frac{60}{121} & \frac{60}{133,1} & \frac{60}{146,4} & \frac{60}{161} \\ & 100\end{array}$




\section{Jaar 0 Jaar 1 Jaar 2 Jaar 3 Jaar 4 Jaar 5}

\begin{tabular}{|c|c|c|c|c|c|c|}
\hline Exploitatiesaldo & - & 7 & 7 & 7 & 7 & 7 \\
\hline Interest & - & 6 & 6 & 6 & 6 & 6 \\
\hline Winst & - & 1 & 1 & 1 & 1 & 1 \\
\hline $\begin{array}{l}\text { Mutatie eigen vermogen } \\
\text { excl. Herwaarderingsreserve }\end{array}$ & 40 & - & - & - & - & - \\
\hline Storting/Uitkering & -40 & 1 & 1 & 1 & 1 & 1 \\
\hline
\end{tabular}

\section{Aktiva met een beperkte gebruiksduur}

Soortgelijke problemen als wij in het voorgaande hebben ontmoet, doen zich voor als de marktwaarden van vaste aktiva met een beperkte gebruiksduur (gebouwen, machines, vervoermiddelen enz.) veranderen. De te maken berekeningen zijn in dit geval echter enigszins gecompliceerder.

Wij gaan er weer vanuit, dat op tijdstip 0 een produktiemiddel met een ge. bruiksduur van $\mathrm{n}$ jaren tegen een prijs van $\mathrm{I}(0)$ wordt aangeschaft. De restwaarde na $\mathrm{n}$ jaren stellen wij gelijk aan 0 . Verder veronderstellen wij, dat de vervangingswaarde van het produktiemiddel tijdens de gebruiksduur verandert met jaarlijkse frakties w(t). Als voorbeeld beschouwen wij evenals hierboven een produktiemiddel met een aanschafprijs van $f 100.000$ aan het eind van het jaar 0 en constante relatieve waardedalingen en -stijgingen met resp. $-10 \%$ en $+10 \%$ per jaar.

De boekwaarden aan het eind van het jaar op basis van de vervangingswaarden,

$$
B(t)=\frac{n-t}{n} \cdot I(t),
$$

worden in onderstaande tabel opgesomd.

BOEKWAARDEN B(c)

\begin{tabular}{lll}
\hline Jaar & Waardedaling & Waardestiging \\
\hline 0 & $f 100.000$ & $f 100.000$ \\
1 & $f 72.000$ & $f 88.000$ \\
2 & $f 48.600$ & $f 72.600$ \\
3 & $f 29.160$ & $f 53.240$ \\
4 & $f 13.122$ & $f 29.282$ \\
5 & $f-$ & $f-$
\end{tabular}

Elk verschil tussen twee opeenvolgende boekwaarden kan worden gesplitst in een afschrijvingsbedrag en een herwaarderingsbedrag. De jaarlijkse afschrijving op basis van de vervangingswaarde $\mathrm{D}(\mathrm{t})$, wordt gedefinieerd als het quotient van de vervangingswaarde $I(t)$ en de gebruiksduur $n$. De jaarlijkse her- 
waardering, $\mathrm{H}(\mathrm{t})$, bepaalt men door de relatieve waardeverandering $w(t)$ te vermenigvuldigen met de boekwaarde aan het eind van het vorige jaar $\mathrm{B}(\mathrm{t}-1)$. Dus:

$$
\begin{aligned}
& D(t)=\frac{1}{n} \cdot I(t) \\
& H(t)=w(t) \cdot B(t-1)
\end{aligned}
$$

De in het gegeven voorbeeld geldende afschrijvingen en herwaarderingen worden in de hiernavolgende tabel vermeld. Zoals blijkt is het verschil tussen de afschrijving en de (positieve of negatieve) herwaardering in elk jaar gelijk aan de verandering van de boekwaarde in dat jaar. Dat dit altijd het geval is, kan op eenvoudige wijze met behulp van de ingevoerde symbolen worden aan-

\begin{tabular}{|c|c|c|c|c|c|c|}
\hline \multirow[t]{2}{*}{ Jaar } & \multicolumn{3}{|c|}{ Waardedaling } & \multicolumn{3}{|c|}{ Waardestijging } \\
\hline & $D(t)$ & $H(t)$ & $B(t-1)-B(t)$ & $D(t)$ & $H(t)$ & $B(t)-B(t-1)$ \\
\hline 1 & $f 18.000$ & $f 10.000$ & $f \quad 28.000$ & $f \quad 22.000$ & $f 10.000$ & $f \quad 12.000$ \\
\hline 2 & $f 16.200$ & $f \quad 7.200$ & $f \quad 23.400$ & $f \quad 24.200$ & $f \quad 8.800$ & $f \quad 15.400$ \\
\hline 3 & $f 14.580$ & $f \quad 4.860$ & $f \quad 19.440$ & $f \quad 26.620$ & $f \quad 7.260$ & $f \quad 19.360$ \\
\hline 4 & $f 13.122$ & $f \quad 2.916$ & $f \quad 16.038$ & $f \quad 29.282$ & ? $f \quad 5.324$ & $f \quad 23.958$ \\
\hline \multirow[t]{2}{*}{5} & $f 11.810$ & $f \quad 1.312$ & $f \quad 13.122$ & $f \quad 32.210$ & $f \quad 2.928$ & $f \quad 29.282$ \\
\hline & $f 73.712$ & $f 26.288$ & $f 100.000$ & $f 134.312$ & $2 f 34.312$ & $f 100.000$ \\
\hline
\end{tabular}
getoond.

De jaarkosten zouden onder de gegeven omstandigheden gelijkgesteld kunnen worden aan de afschrijvingen op basis van de vervangingswaarde minus de hierboven berekende (negatieve of positieve) herwaardering plus de financieringskosten als produkt van de gemiddelde vermogenskosten en de boekwaarde aan het begin van het beschouwde jaar. Men verkrijgt dan:

$$
\begin{aligned}
& K(t)=D(t)-H(t)+r \cdot B(t-1)= \\
& \frac{1}{n} I(t)-w(t) \cdot B(t-1)+r \cdot B(t-1)= \\
& \frac{1}{n} I(t)+[r-w(t)] \cdot B(t-1)= \\
& \frac{1}{n} I(t)+[r-w(t)] \cdot \frac{n-t+1}{n} \cdot I(t-1) .
\end{aligned}
$$

De aldus gedefinieerde jaarkosten dalen of stijgen overeenkomstig het verloop van de vervangingswaarden van het produktiemiddel. De reeks $K(1) \ldots K(n)$ 
kan bovendien in zoverre als een reeks minimaal vereiste vergoedingen voor het gebruik van het produktiemiddel worden beschouwd, dat de contante waarde hiervan gelijk aan het investeringsbedrag I $(0)$ is $\left.{ }^{5}\right)$. Een nadeel van de kosten $\mathrm{K}(\mathrm{t})$ is echter, dat de omvang hiervan in elk jaar mede wordt bepaald door de datum waarop de desbetreffende aktiva zijn aangeschaft. De reden hiervan is, dat zowel de financieringskosten als de herwaarderingen mede op basis van de faktor $\frac{\mathrm{n}-\mathrm{t}+1}{\mathrm{n}}$ worden bepaald: Afhankelijk van het tijdstip waarop het beschouwde produktiemiddel is aangeschaft, worden de grootheden $r \cdot I(t-1)$ en $w(t) \cdot I(t-1)$ in een bepaald jaar $t$ vermenigvuldigd met de faktor $\frac{1}{n}, \frac{2}{n} \ldots, \frac{n-1}{n}$ of 1 . Aangezien er geen redenen zijn waarom men bijv. de beoordeling van verkoopprijzen van eindprodukten zou moeten laten afhangen van de data waarop het eigen bedrijf zijn produktiemiddelen heeft ingekocht, vormt het hier beschouwde kenmerk een ernstig nadeel van de besproken calculatiemethoden.

Aan het zojuist genoemde bezwaar kan men tegemoet komen door de kosten in elk jaar $t$ niet te berekenen op basis van het dan geldende quotiënt $\frac{n-t+1}{n}$ maar het gemiddelde van deze quotiënten tijdens de gehele gebruiksduur van het produktiemiddel in de calculatie op te nemen. De kosten in jaar $\mathrm{t}$ worden dan gelijkgesteld aan:

$$
\begin{aligned}
\bar{K}(t)= & \frac{1}{n} I(t)-w(t) \cdot \frac{1}{2} \cdot \frac{n+1}{n} \cdot I(t-1)+r \frac{1}{2} \cdot \frac{n+1}{n} I(t-1)= \\
& \frac{1}{n} I(t)+[r-w(t)] \cdot \frac{1}{2} \cdot \frac{n+1}{n} \cdot I(t-1) .
\end{aligned}
$$

De bedragen $\bar{K}(t)$ volgens het gegeven voorbeeld worden hieronder vermeld. Zoals blijkt vertonen deze kosten een dalend of stijgend verloop. Een nadeel van de hier bedoelde calculatiewijze is, dat de contante waarde van een reeks bedragen $\bar{K}(1), \ldots, \bar{K}(n)$ tegen de vermogenskosten $r$ afwijkt van de investering $I(0)$. De omvang van deze afwijking wordt hieronder verder besproken.

5) $\sum_{t=1}^{n} \frac{K(t)}{(1+r)^{t}}=\sum_{t=1}^{n} \frac{D(t)-H(t)+r \cdot B(t-1)}{(1+r)^{t}}=$

$\sum_{t=1}^{N} \frac{B(t-1)-B(t)+r \cdot B(t-1)}{(1+r)^{t}}=I(0)$ 
JAARKOSTEN $\bar{K}(t)$

\begin{tabular}{|c|c|c|c|c|c|c|c|c|}
\hline \multirow[t]{2}{*}{ Jaar } & \multicolumn{4}{|c|}{ Waardedaling } & \multicolumn{4}{|c|}{ Waardestiging } \\
\hline & $D(t)$ & $\bar{H}(t)$ & Fin.k. & $\bar{K}(t)$ & $D(t)$ & $H(t)$ & Fin.k. & $\bar{K}(t)$ \\
\hline 1 & $f 18.000$ & $f 6.000$ & $f \quad 7.200$ & $f \quad 31.200$ & $f 22.000 f$ & 6.000 & $f 7.200$ & $f \quad 28.200$ \\
\hline 2 & $f 16.200$ & $f \quad 5.400$ & $f \quad 6.480$ & $f \quad 28.080$ & $f 24.200 f$ & 6.600 & $f 7.920$ & $f \quad 25.520$ \\
\hline 3 & $f 14.580$ & $f \quad 4.860$ & $f \quad 5.832$ & $f \quad 25.272$ & $f 26.620 f$ & 7.260 & $f \quad 8.712$ & f 28.072 \\
\hline 4 & $f 13.122$ & $f 4.374$ & $f \quad 5.249$ & $f \quad 22.745$ & $f 29.282 f$ & 7.986 & $f \quad 9.583$ & f $\quad 30.879$ \\
\hline 5 & $f 11.810$ & $f \quad 3.937$ & $f \quad 4.724$ & $f 20.471$ & $f 32.210 f$ & 8.785 & $f 10.542$ & $f \quad 33.967$ \\
\hline & $f 73.712$ & $f 24.571$ & $f 29.485$ & $f 127.768$ & $f 134.312$ & 36.631 & $f 42.957$ & $f 141.638$ \\
\hline
\end{tabular}

Als alternatieven voor de grootheden $K(t)$ en $\bar{K}(t)$ kunnen op de derde plaats jaarkosten op basis van een samengestelde-interestberekening worden be. paald. Ter omschrijving hiervan merken wij op, dat de jaarkosten in principe overeenkomstig de vervangingswaarden moeten veranderen of m.a.w. in een vaste verhouding tot de respectievelijke vervangingswaarden moeten staan. Geeft men deze verhouding weer door $\mu$ en stelt men de jaarkosten op basis van een samengestelde-interestberekening voor door $A(t)$, dan moet dus in elk jaar gelden:

$$
\mathrm{A}(\mathrm{t})=\mu . \mathrm{I}(\mathrm{t})
$$

Opdat de grootheden $A(t)$ als jaarkosten zijn te beschouwen, moet de contante waarde hiervan bij de gegeven vermogenskosten $r$ gelijk zijn aan het investeringsbedrag $\mathrm{I}(0)$. Dus:

$$
\sum_{t=1}^{\mathrm{n}} \frac{\mu \mathrm{I}(\mathrm{t})}{(1+\mathrm{r})^{\mathrm{t}}}=\mathrm{I}(0)
$$

of wel:

$$
\mu=\frac{I(0)}{\sum_{t=1}^{n} \frac{I(t)}{(1+r)^{t}}}=\frac{I(0)}{\sum_{t=1}^{n} \frac{[1+w(t)]^{t} \cdot I(0)}{(1+r)^{t}}}=\frac{1}{\sum_{t=1}^{n}\left(\frac{1+w(t)}{1+r}\right)^{t}}
$$

Substitueert men deze uitdrukking voor $\mu$ in de vergelijking $\mathrm{A}(\mathrm{t})=\mu \mathrm{I}(\mathrm{t})$, dan verkrijgt men:

$$
A(t)=\frac{I(t)}{\sum_{t=1}^{n}\left(\frac{1+w(t)}{1+r}\right)^{t}}
$$

of bij een constante relatieve waardeverandering met een fraktie $w$ per jaar:

$$
A(t)=\frac{I(t)}{\sum_{t=1}^{n}\left(\frac{1+w}{1+r}\right)^{t}}
$$


De op basis van het gegeven voorbeeld te berekenen jaarkosten $A(t)$ worden hieronder weergegeven:

JAARKOSTEN A(t)

\begin{tabular}{lll}
\hline Jaar & Daling & Stijging \\
\hline 1 & $f 33.086$ & $f 23.215$ \\
2 & $f 29.777$ & $f 25.536$ \\
3 & $f 26.799$ & $f 28.090$ \\
4 & $f 24.120$ & $f 30.899$ \\
5 & $f 21.708$ & $f 33.988$ \\
& $f 135.490$ & $f 141.728$ \\
\hline
\end{tabular}

Zoals bekend is, kan men in geval van algemene waardeveranderingen onder. scheid maken tussen werkelijke of wel effektieve vermogenskosten (cq. rentevoeten) en reële vermogenskosten. Stelt men de reële vermogenskosten voor door $\mathrm{r}_{0}$, dan geldt:

$$
r_{0}=\frac{1+r}{1+w}-1
$$

Op basis hiervan vindt men onderstaande uitdrukking voor $\mathrm{A}(\mathrm{t})$. Bij een algemene waardeverandering bestaan de jaarkosten $A(t)$ dus uit het quotiënt van de vervangingswaarde van het produktiemiddel en een annuiteitsfaktor op ba. sis van de reële vermogenskosten.

$$
A(t)=\frac{I(t)}{\sum_{t=1}^{n} \frac{1}{\left(1+r_{0}\right)^{t}}}
$$

Aangezien de grootheden $\mathrm{A}(1), \ldots, \mathrm{A}(\mathrm{n})$ overeenkomstig de vervangingswaar. den dalen of stijgen terwijl de contante waarde hiervan per definitie gelijk is aan het investeringsbedrag $\mathrm{I}(0)$, geven deze grootheden in het algemeen een bevredigend beeld van het kostenverloop. Het feit dat de grootheden $A(t)$ via een samengestelde-interestberekening moeten worden bepaald, kan men in de praktijk bezwaarlijk vinden. Om deze reden kan men aan de jaarkosten $\overline{\mathrm{K}}(\mathrm{t})$ de voorkeur geven.

De verhouding tussen de jaarkosten $\overline{\mathrm{K}}(\mathrm{t})$ en de jaarkosten $\mathrm{A}(\mathrm{t})$ is bij een ge. lijkblijvende relatieve waardeverandering $w(t)=w$ in alle jaren constant. Enkele waarden van deze verhouding worden hieronder vermeld. Zoals blijkt is $\overline{\mathrm{K}}(\mathrm{t})$ in het merendeel van de gevallen kleiner dan A(t). De jaarkosten $\overline{\mathbf{K}}(\mathrm{t})$ zijn dus doorgaans lager dan de jaarlijkse vergoeding die minimaal vereist is om de aanschaf van een produktiemiddel financiëel verantwoord te doen zijn. Daarbij dient echter te worden aangetekend, dat de grootste afwijkingen tussen $\bar{K}(t)$ en $\mathrm{A}(\mathrm{t})$ - welke volgens de tabel optreden bij een voortdurende waardedaling gedurende een betrekkelijk lange reeks jaren - zich in de praktijk zelden voor. doen. 


\begin{tabular}{llll}
\hline$w=-0,1$ & $n=5$ & $n=10$ & $n=20$ \\
$r=0,05$ & 0,97 & 0,91 & 0,80 \\
$r=0,10$ & 0,96 & 0,89 & 0,76 \\
$r=0,20$ & 0,95 & 0,84 & 0,72 \\
$w=0,1$ & & & \\
$r=0,05$ & 0,99 & 0,97 & 0,81 \\
$r=0,10$ & 1,00 & 1,00 & 1,00 \\
$r=0,20$ & 1,01 & 0,99 & 0,93 \\
\hline
\end{tabular}

Teneinde het verloop van de jaarrekeningen onder de gegeven omstandigheden te kunnen toelichten, nemen wij aan dat een bedrijf steeds over $n$ identieke produktiemiddelen met eenzelfde gebruiksduur beschikt, dat jaarlijks één van deze produktiemiddelen buiten gebruik wordt gesteld en dat tegelijkertijd één nieuw produktiemiddel wordt aangeschaft. Het bedrijf heeft dan aan het eind van elk jaar $\mathrm{n}$ produktiemiddelen met resterende gebruiksduren van resp. $1,2, \ldots,(n-1)$ en $n$ jaren.

Als voorbeeld beschouwen wij een complex van vijf produktiemiddelen met de eerder genoemde kenmerken. De totale boekwaarde van deze produktie. middelen op basis van de vervangingswaarden is aan het eind van elk jaar $t$ gelijk aan 3. I (t); de afschrijvingen op basis van de vervangingswaarden zijn steeds gelijk aan I(t); de totale herwaardering bedraagt telkens $w(t) \cdot 3 \cdot I(t-1)$.

De respectievelijke totale boekwaarden aan het eind van de jaren $0 \mathrm{t} / \mathrm{m} 5$ worden in de balansen op blz. 501 en 502 weergegeven. Nadat de aktivawaar den zijn bepaald, kunnen de balansen worden gecompleteerd onder de ver. onderstelling dat de verhouding tussen het eigen en het vreemde vermogen op 40/60 wordt gehandhaafd. De resultatenrekeningen op blz. 502 zijn opge. steld onder de veronderstelling, dat de jaarlijkse exploitatiesaldi gelijk zijn aan $5 \cdot \overline{\mathrm{K}}(t)$. Voorts is aangenomen dat in elk jaar $10 \%$ interest over het vreemde vermogen aan het eind van het daaraan voorafgaande jaar moet worden be. taald.

Men kan zeggen, dat de aldus opgestelde jaarrekeningen een duidelijk beeld van de financiële positie en de resultaten van een bedrijf geven: De aktivawaar. den, het eigen vermogen en het vreemde vermogen veranderen volgens de balansen met $10 \%$ per jaar. De winsten zijn in elk jaar gelijk aan $15 \%$ van het eigen vermogen aan het eind van het daaraan voorafgaande jaar.

Als zich een algemene inflatie voordoet, kan elke jaarwinst weer worden verdeeld in de inflatiecorrectie op het eigen vermogen (gelijk aan de inflatie. faktor maal het eigen vermogen aan het begin van het jaar) en de reële winst. Ook hier kan worden opgemerkt, dat de inflatiecorrectie een schijnwinst vormt die geheel aan de eigenaren zou behoren toe te komen en derhalve als een aftrekpost in fiscale jaarrekeningen zou moeten worden opgenomen. Deze calculatiemethode zou in geval van inflatie moeten worden toegepast, ongeacht de mate van waardedaling of -stijging van de specifieke produktiemiddelen van het beschouwde bedrijf. 
De in de vorige paragraaf genoemde variant van het vervangingswaardestelsel waarbij de positieve herwaarderingen niet als bijdragen tot de winst worden beschouwd maar rechtstreeks aan een Herwaarderingsreserve als onderdeel van het eigen vermogen worden toegevoegd, kan ook worden toegepast op produktiemiddelen met een beperkte gebruiksduur. Doordat de herwaarderingen dan volledig aan het eigen vermogen worden toegevoegd, neemt de verhouding tussen het eigen en het vreemde vermogen geleidelijk toe. Aangezien geen algemene redenen hiervoor bestaan, verdient de toepassing van deze variant van het vervangingswaardestelsel echter geen algemene toepassing.

De verhouding tussen het eigen en het vreemde vermogen wordt nog verder vergroot, als men zogenaamde inhaalafschrijvingen ten laste van de resultatenrekening brengt. De gedachte achter dit systeem is, dat het eigen vermogen tijdens de gebruiksduur van een produktiemiddel dient toe te nemen met de totale stijging van de vervangingswaarde. Daartoe bepaalt men jaarlijks het bedrag waarmee de vervangingswaarde is gestegen. Het verschil tussen dit bedrag wordt tezamen met de "normale" afschrijvingen $\frac{1}{n} \mathrm{I}(\mathrm{t})$ ten laste van de resultatenrekening gebracht en tezamen met de herwaardering van de boek. waarde $w(t) . B(t-1)$ aan het eigen vermogen toegevoegd. Na het voorgaande zal het zonder meer duidelijk zijn, dat de hierdoor bewerkstelligde extra vergroting van het eigen vermogen ongemotiveerd is.

Jaarrekeningen in geval van waardedaling ( 1000 gld.)

BALANSEN PER 31 DECEMBER

jaar 0 jaar 1 jaar 2 jaar 3 jaar 4 jaar 5

Debet

Aktiva

$300 \quad 270 \quad 243 \quad 218,7 \quad 196,8 \quad 177,1$

Credit

Eigen vermogen

Vreemd vermogen

$\begin{array}{rrrrrr}120 & 108 & 97,2 & 87,5 & 78,7 & 70,8 \\ \frac{180}{300} & \frac{162}{270} & \frac{145,8}{243} & \frac{131,2}{218,7} & \frac{118,1}{196,8} & \frac{106,3}{177,1}\end{array}$


RESULTATENREKENINGEN EN WINSTVERDELINGEN

\begin{tabular}{|c|c|c|c|c|c|c|}
\hline & jaar $O$ & jaar 1 & jaar 2 & jaar 3 & jaar 4 & jaar 5 \\
\hline Exploitatiesaldo & PM & 156 & 140,4 & 126,4 & 113,7 & 102,4 \\
\hline Afschrijvingen & PM & 90 & 81 & 72,9 & 65,6 & 59,1 \\
\hline Herwaardering & PM & 30 & 27 & 24,3 & 21,9 & 19,7 \\
\hline Interest & PM & 18 & 16,2 & 14,6 & 13,1 & 11,8 \\
\hline Winst & PM & 18 & 16,2 & 14,6 & 13,1 & 11,8 \\
\hline Mutatie eigen vermogen & PM & -12 & $-10,8$ & $-9,7$ & $-8,8$ & $-7,9$ \\
\hline Storting/Uitkering & PM & 30 & 27 & 24,3 & 21,9 & 19,7 \\
\hline
\end{tabular}

Jaarrekeningen in geval van waardestijging ( $\times 1000$ gld.)

BALANSEN PER 31 DECEMBER

jaar 0 jaar 1 jaar 2 jaar 3 jaar 4 jaar 5

\begin{tabular}{lcccccc}
\hline $\begin{array}{l}\text { Debet } \\
\text { Aktiva }\end{array}$ & 300 & 330 & 363 & 399,3 & 439,2 & 483,2 \\
$\begin{array}{l}\text { Credit } \\
\text { Eigen vermogen }\end{array}$ & 120 & 132 & 145,2 & 159,7 & 175,7 & 193,3 \\
$\begin{array}{l}\text { Vreemd vermogen } \\
\text { 180 }\end{array}$ & $\frac{198}{300}$ & $\frac{217,8}{330}$ & $\frac{239,6}{363}$ & $\frac{263,5}{399,3}$ & $\frac{289,9}{439,2}$ & $\frac{483,2}{48,2}$
\end{tabular}

RESULTATENREKENINGEN EN WINSTVERDELINGEN

\begin{tabular}{lcccccc}
\hline & jaar 0 & jaar 1 & jaar 2 & jaar 3 & jaar 4 & jaar 5 \\
\hline Exploitatiesaldo & $\mathrm{PM}$ & 116 & 127,6 & 140,4 & 154,4 & 169,8 \\
Afschrijvingen & $\mathrm{PM}$ & 110 & 121 & 133,1 & 146,4 & 161,1 \\
Herwaardering & $\mathrm{PM}$ & 30 & 33 & 36,3 & 39,9 & 43,9 \\
Interest & $\mathrm{PM}$ & 18 & 19,8 & 21,8 & 24 & 26,4 \\
Winst & $\mathrm{PM}$ & 18 & 19,8 & 21,8 & 23,9 & 26,2 \\
Mutatie eigen vermogen & $\mathrm{PM}$ & 12 & 13,2 & 14,5 & 16 & 17,6 \\
Storting/Uitkering & $\mathrm{PM}$ & $\mathbf{6}$ & 6,6 & 7,3 & 7,9 & 8,6
\end{tabular}

